\title{
TEMPORAL AND SPATIAL RAINFALL VARIABILITY IN THE URBANIZED AREA OF CRACOW
}

\author{
Elżbieta Jarosińska ${ }^{\bowtie}$, Marek Bodziony \\ Department of Water Engineering and Water Management, Cracow University of Technology, Warszawska 24, Kraków, Poland
}

\begin{abstract}
Aim of the study

The aim of this study is to provide temporal-spatial characteristics of rainfall distribution variability in the Cracow area, based on the new method of determining spatial distribution, as well as establishing the areas of the highest and lowest rainfall variability as compared to a multi-annual period.
\end{abstract}

\begin{abstract}
Material and methods
For the calculations, 10-minute precipitation data sequences were used from the period of 2013-2016 (recorded by the MPWiK's precipitation monitoring system in Cracow; from 18 precipitation stations) as well as daily and monthly precipitation data sequences from the multi-annual period 1951-2018 (recorded at the Kraków-Obserwatorium station by the IMGW).The rainfalls observed in the period of 2013-2016 were compared to the rainfalls from the multi-annual period of 1951-2018 contrasting the average monthly and annual precipitation totals, as well as the maximum daily precipitation totals in the summer months. The comparison was made by calculating the degree of exceedance or subceedance of the average values in [\%] in relation to the Kraków-Obserwatorium station, which was chosen as the benchmark. The last stage of the study was to create, in the geodata and geoinformation environment, bitmaps of spatial distribution of precipitation in the Cracow area. For drawing the isolines, the interpolation method was used.
\end{abstract}

\section{Results and conclusions}

That methodology: a) uses data from multiple precipitation stations in the researched area, b) allows for the comparison of precipitation quantities for a given period versus the data from the multi-annual period (utilizing a benchmark), c) continuously monitor precipitation variability occurring in the researched area.

Keywords: rainfall, urban climate, urbanized areas, rainfall monitoring

\section{INTRODUCTION}

Climate in a given area is shaped by a number of factors, including rainfalls. In the summer in Poland, short and high-intensity rainfalls occur in the areas where there are favorable conditions for the development of strong ascending air currents. The totals of this type of rainfalls mainly depend on the amount of water in a cloud, its size and the speed of its movement.
There is a view that on both global (Kędziora, 1995) and local scales (Matuszko and Węglarczyk, 2018) the frequency of cloud cover occurrence is variable. The presence of multi-level clouds (stratus, nimbostratus, altostratus) producing long low-intensity rainfalls is decreasing, and the presence of vertical clouds (cumulus, cumulonimbus) is increasing, bringing about short high-intensity downpours (Sun and Groisman, 2000; Matuszko, 2003; Wibig, 2008). Clouds of the cumu-

凶e-mail: elzbieta.jarosinska@pk.edu.pl 
lus type are the product of a very strong convection over the heated areas, mostly in urban agglomerations characterized by dense building development. According to Lewińska (2000), cumulus clouds are formed approximately 300-600 meters higher over urban areas than outside of cities. Matuszko and Węglarczyk (2014) have shown that over the course of a multi-annual period in Cracow, the cloud cover in terms of quantity has a tendency to decrease and the reason for that decreasing is the predominance of high-pressure systems, recorded in the last two decades of the 20th century.

Precipitation is characterized by high variability (Bracken et al., 2008; Vitola et. al., 2012; Fendeková, 2014; Molina-Sanchis et. al., 2016) and shows discontinuity in terms of time and space. In Polish research, precipitation is often discussed in terms of time and space, both on a national (Wibig, 2009; Kotowski et. al., 2010; Nidzgorska-Lencewicz and Czarnecka, 2012; Szwed, 2019) and regional scale (Radzka, 2014; Ilnicki et. al., 2015; Kożuchowski, 2016; Twardosz, 2016). According to the European Environment Agency, the climate of Poland, as well as of some of the European continent, faces risks from factors including increasing temperatures, decreasing precipitation in the summers and floods (EEA, 2018).

Studies of rainfall, as precipitation occurring in summer months in the Cracow area, have been carried out a number of times, however they were often based on data from only one or several stations, located within its area. Between 2012 and 2016, there were several new precipitation stations set up in the Cracow area, which allows for monitoring rainfall and, consequently, gathering detailed information regarding the temporal-spatial precipitation variability.

The aim of this study is to provide temporal-spatial characteristics of rainfall distribution variability in the Cracow area, based on the new method of determining spatial distribution, as well as establishing the areas of the highest and lowest rainfall variability as compared to a multi-annual period.

\section{STUDY AREA}

The area of study includes the territory of the city of Cracow. Located in the catchment of the Vistula river, it is the second biggest city in Poland (GUS, 2019), both in terms of the number of inhabitants $(771,100$ in 2018), and surface $\left(327 \mathrm{~km}^{2}\right)$. Elevation ranges from $187 \mathrm{~m}$ a.s.l. in the Vistula valley up to $383.6 \mathrm{~m}$ a.s.1. at Piłsudski's Mound (see: Fig. 1). As a large urban center, it is especially exposed to changeable climate factors. From among all of the analyzed climate-related phenomena (MPA, 2018), based on their character and the frequency of occurrence within a period of 35 years (1981-2015), the main risks faced by the city include: heat waves, long rainfall-free periods combined with maximum temperature over $25^{\circ} \mathrm{C}$, torrential rains causing local floods, namely urban floods. The phenomena shaping the climate of Cracow are particularly unfavorable. These include increasing urbanization progressing at variable rates in different areas of the city, catchment sealing, the decreasing of the green surfaces, the worsening of the urban ventilation conditions and the increasing of the range and intensity of the urban heat island. It is observed that the speed of wind is decreasing in the urbanized area of Cracow by $20-30 \%$ as compared to its outer areas (Matuszko, 2007), or even by $30-50 \%$ in the city center (Nidzgorska-Lencewicz and Czarnecka, 2012). The direction of wind in the Cracow area largely depends on both the landscape and the buildings. Alongside the valley of the Vistula, the dominant directions are westerly and easterly (Błażejczyk, 2013; Matuszko at al., 2015). Outside of the city area, the dominant winds are south-westerly (Błażejczyk, 2013). Cracow is characterized by higher precipitation in the city center than in the outer areas. This can be explained by Cracow's location in a valley which is conducive to frequent temperature inversion. This results in the accumulation of harmful fumes and gases in the air layers close to the ground, causing the moisture to accumulate which, in turn, affects the rainfalls in the city. The climate of Cracow is typically urban, which is characteristic of areas with the population of approximately 1 million inhabitants (Nidzgorska-Lencewicz and Mąkosza, 2016).

\section{MATERIALS AND METHODS}

For the calculations, 10-minute precipitation data sequences were used from the period of 2013-2016, as well as daily and monthly precipitation data sequences from the multi-annual period 1951-2018 (Raw rainfall 
data was recorded by the system of weighing rain gauges by the MPWiK (located on open areas) as impulses representing $0.2 \mathrm{~mm}$ increase of rainfall. Each impulse was assigned the date and time of occurrence with accuracy of 1 second. While preparing the data, it was necessary to discretize it to the data of 10-minute time steps. The discretization was done using a macro designed in MS Excel.). The precipitation data from the shorter period was recorded by the MPWiK's (The Municipal Water and Sewerage Company) precipitation monitoring system in Cracow, whereas the data from the multi-annual period was recorded at the Kraków-Obserwatorium station, located within the botanical garden in the city center, as recorded by the IMGW (The IMGW's data base: https://dane.imgw.pl). The rainfalls for this study were taken from 18 precipitation stations, distributed evenly in the Cracow area (see: Fig. 1).

In the first stage of the study, the following measurements were calculated: 1) daily precipitation totals, 2) maximum daily precipitation totals, 3) annual precipitation totals, and 4) average monthly and 5) average annual precipitation totals from the summer months of 2013-2016 and the multi-annual period of 1951-2018.

Following the first stage, the rainfalls observed in the period of 2013-2016 were compared to the rain- falls from the multi-annual period of 1951-2018 contrasting the average monthly and annual precipitation totals, as well as the maximum daily precipitation totals in the summer months. The comparison was made by calculating the degree of exceedance or subceedance of the average values in [\%] in relation to the Kraków-Obserwatorium station, which was chosen as the benchmark.

The last stage of the study was to create, in the geodata and geoinformation environment (QGis v. 3.4 software), bitmaps of spatial distribution of precipitation in the Cracow area. For drawing the isolines, the interpolation method was used. As a result, there were created 5 monthly (see: Fig. 2) and 4 annual maps (see: Fig. 3) of isohyets cut off every $5 \%$.

In order to analyze the trend of the changeability of the rainfall total in a multi-annual period in the researched catchment, the trend method was applied. The non-parametric statistical test by Mann-Kandall is often used in the analyses of climate and hydrological values trends (Maksymiuk at al., 2008; Banasik at al., 2013, Kaźmierczak, 2014). It consists in verifying the null hypothesis $\mathrm{H} 0$ stating the lack of trend in the data based on the non-parametric rank correlation coefficient (Kendall's statistical $\tau$ ) (Węglarczyk, 2010; Rutkowska and Ptak, 2012). Kendall's statistics $\tau$ takes

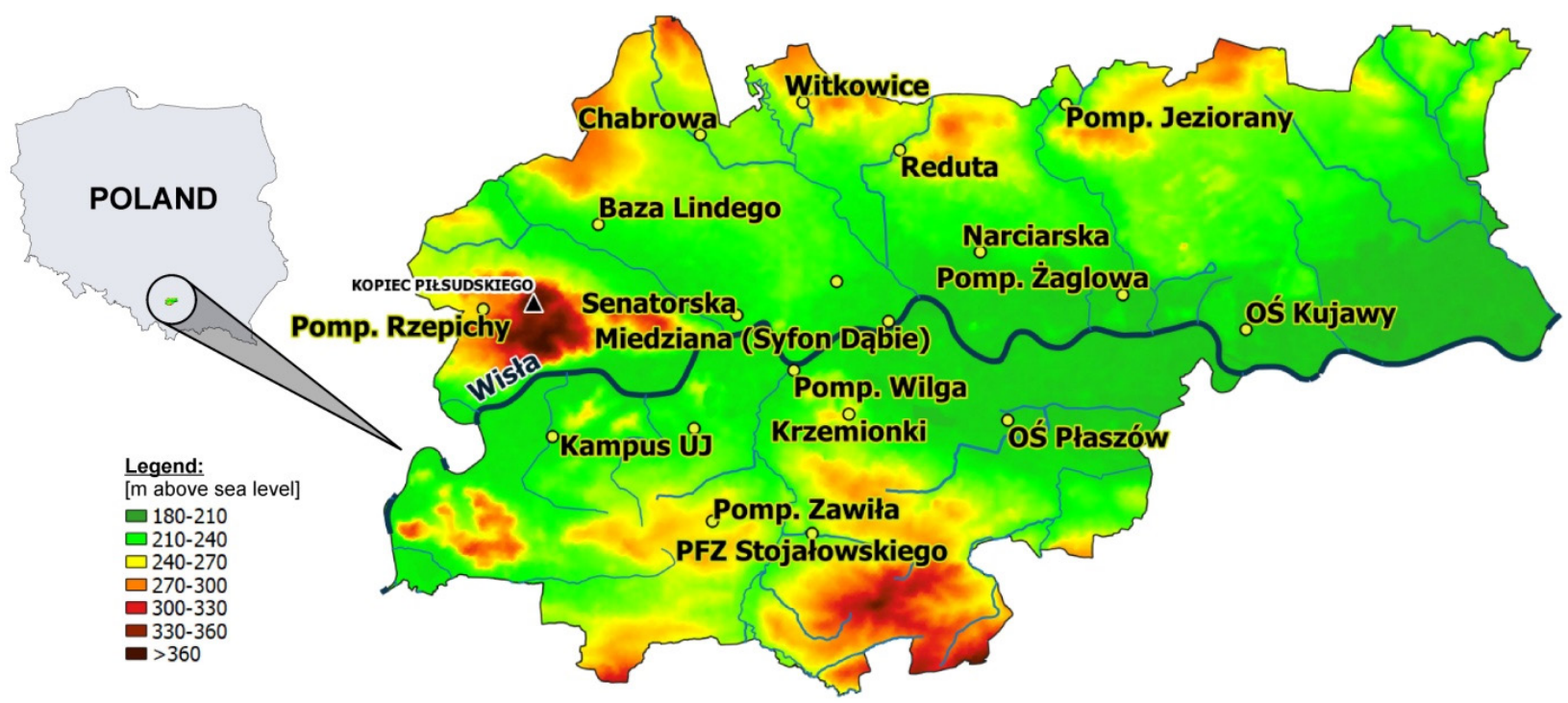

Fig. 1. Location of 18 precipitation stations of the MPWiK and the Kraków-Obserwatorium station (benchmark) in the area of Cracow 
the values from the $[-1 ; 1]$ range. The positive values show an increasing trend, while the negative values show a decreasing trend. The values close to 0 show (after the null hypothesis) that no trend is present. This paper assumes, after Kaźmierczak (2014), that a significant change (decreasing or increasing) is one at over $95 \%(<0.05)$. A trend close to statistically significant is assumed to be one at $90-95 \%(0.05 \div 0.10)$. $75-90 \%(0.10-0.25)$ represents merely a tendency to change, and values below $75 \%(>0.25)$ were assumed to be insignificant and with no defined change of direction. The calculations were made using the statistical package XLSTAT, an MS Excel statistical tool designed for data analysis.

\section{RESULTS AND DISCUSSION}

Based on the data from the multi-annual period of 1951-2018 for the Kraków-Obserwatorium station, average monthly and annual precipitation totals were derived (see: Table 1) as well as maximum daily totals (see: Table 2).

Table 1. Average monthly and annual precipitation totals [in $\mathrm{mm}$ ] between May-September 1951-2018

\begin{tabular}{cccccccc}
\hline Month & V & VI & VII & VIII & IX & $\begin{array}{c}\sum \text { YEAR } \\
\text { (V-IX) }\end{array}$ & $\begin{array}{c}\Sigma \\
\text { YEAR }\end{array}$ \\
\hline $\begin{array}{c}\text { Rainfall } \\
{[\mathrm{mm}]}\end{array}$ & 77.0 & 93.5 & 95.4 & 82.7 & 59.4 & 408 & 684 \\
\hline
\end{tabular}

Source: author's own calculations based on data from the Kraków -Obserwatorium station.

Table 2. Maximum daily precipitation total [in $\mathrm{mm}$ ] for particular months and a year between May-September 1951$-2018$

\begin{tabular}{ccccccc}
\hline Month & V & VI & VII & VIII & IX & YEAR \\
\hline $\begin{array}{c}\text { Rainfall [mm] } \\
\text { max day }\end{array}$ & 81.0 & 79.0 & 85.2 & 74.4 & 99.0 & 99.0 \\
\hline
\end{tabular}

Source: author's own calculations based on data from the Kraków -Obserwatorium station

Fig. 2 and 3 present the results of the comparison made between the data from 2013-2016 at the MP-
WiK's stations and the multi-annual period data at the benchmark Kraków-Obserwatorium.

Rainfalls occurring in the summer months in the Cracow area are characterized by high variability, depending on place and time frame. In the timeframe of a year, one can assume both months characterized by heavy rainfalls and months of scarce rainfalls as compared to the average values from the multi-annual period. A comparative analysis of monthly rainfall totals has shown that the wettest month was June 2013, when the exceedance of the average value from the multi-annual period at the following stations was $>90 \%$, i.e.: Senatorska (139.6\%), Pomp. Wilga (139.1\%), Miedziana (Syfon Dąbie) (135.3\%), PFZ Stojałowskiego (130.2\%), Pomp. Senatorska (121.8\%), Pomp. Senatorska (118.4\%), Pomp. Żaglowa (103.9\%) and Pomp. Zawiła (96.6\%); July 2014, when the exceedance of the average value from the multi-annual period at the following stations was $>70 \%$, i.e.: OŚ Płaszów (141.9\%), PFZ Stojałowskiego (88.7\%), Pomp. Senatorska (87.6\%), Pomp. Jeziorany (85.1\%), Witkowice (82.0\%), OŚ Kujawy (74.4\%), Pomp. Wilga (74.2\%) and May 2014, where the exceedance value of the average from the multi-annual period at the following stations is $>60 \%$, i.e.: Pomp. Zawiła (95.8\%), OŚ Płaszów (93.2\%), PFZ Stojałowskiego (70.6\%) and Pomp. Wilga (69.9\%). The least wet months were those with over $50 \%$ subceedance of the average value from the multi-annual period, i.e. May, July and August 2013, June and July 2015, June and September 2016 (see: Fig. 2). The exceedance of the average value from the multi-annual period is marked in blue on Figure 2, while the subceedance of the value in beige. The average monthly rainfall total on the benchmark in the particular months of the multi-annual period 2013-2016 was marked on the ordinate axis " 0 " in the graph. The exceedance percentage of the average value from the multi-annual period is marked to the right from " 0 ", and the subceedance percentage to the left from " 0 ".

The results of the comparative analysis of the annual rainfall totals show that summer months of 2013 and 2014 were characterized by higher values than the average annual rainfall totals in the city. In 2015 and 2016, annual rainfall totals calculated in the summer months showed a decreasing tendency as compared to the average annual rainfall total (see: Fig. 3). Owing to 
the short study period, it is difficult to say if this tendency will remain in following years. Thus rainfall in Cracow should be continuously monitored. It was also observed that rainfalls of lower values than the average annual total occurred mainly in the vicinity of the precipitation stations located in the center of Cracow (i.e. Pomp. Wilga, Senatorska, Miedziana (Syfon Dąbie) - in 2013) and in the south-east (i.e. Pomp. Zawiła, PFZ Stojałowskiego, OŚ Płaszów, Pomp. Kujawy, Pomp. Żaglowa, Pomp. Jeziorany - in 2014). Perhaps this tendency may not be a direct result of the recent change in winds direction in the Cracow area, however it is an indication of the decrease in the speed of wind in the urbanized part of the city as compared to its outer areas, as a study by Matuszko (2007) shows. This, in turn, results in poor urban pollution ventilation, which forms cores of steam condensation in air, increasing the amount and frequency of precipitation, according to Błażejczyk (2013).

It has been observed that the south-eastern area of Cracow was also characterized by the occurrence of intense rainfalls type II, III and IV (Jarosińska, 2018), as well as rainfalls of $I 0.10 \mathrm{~mm} \cdot \mathrm{min}^{-1}$ (Jarosińska, 2019). This study has shown that the places of rainfall occurrence in Cracow are only partially consistent with the conclusions made 14 years ago by Olechnowicz-Bobrowska et. al. (2005), who showed that far more precipitation occurs in the southern and western parts of the city, as compared to the north and east remaining in the rain shadow.

The spatial distribution of annual precipitation totals from 2013-2016 in relation to the average from the multi-annual period is shown on the maps in Figure 4. The graphs present the differences as \% proportions in the annual rainfall total values between the benchmark (the Kraków-Obserwatorium station) and the particular gauging sites. Each year is represented by an individual graph.

Straight lines were drawn between the benchmark and the sites, representing the direction of rainfall occurrence. Axes designed in this way were then used to show the rainfall differences in \%. A straight line means that a rainfall at the Kraków-Obserwatorium station was smaller than at the gauging site. A broken line means that a rainfall at the Kraków-Obserwatorium station was greater than at the gauging site.
This illustrates not only the differences between the rainfall values for particular years but also the trends in the rainfall distribution in the Cracow area.

This distribution in the Cracow area is typically highly variable. Within the area of the stations located mainly to the west (i.e. Pomp. Rzepichy, Baza Lindego and OŚ Kostrze - in 2015) and in the north (i.e. Chabrowa, Witkowice, Reduta and Pomp. Jeziorany in 2016), the occurring rainfalls showed a decreasing tendency in terms of quantity as compared to the average annual value. It appears that this is not a result of the land's hypsometry (all of the above-mentioned stations are located at fairly similar elevations), however, as according to Błażejczyk (2013), terrain plays a vital role in the shaping of annual precipitation totals in the Cracow area and nearby. The decreasing rainfall volume may be affected by the high rate of urban sealing in these areas. According to the MPA (2018), sealing of the area located to the west is within the range of 41-60\% - Pomp. Rzepichy, 61-80\% - Baza Lindego and $21-30 \%$ - OŚ Kostrze, and in the north 41-60\% - Chabrowa and Pomp. Jeziorany, 31-40\% - Witkowice and $0-10 \%$ - Reduta. Owing to the tendency for increasing building development in the city, it is necessary to monitor further and analyze the amounts of rainfall occurring in the Cracow area over the course of the following years, as well monitor the directions of their movement.

It was additionally observed that the maximum daily rainfall total from the multi-annual period was significantly lower, and the values ranged from $-60.0 \%$ in 2013 (Pomp. Jeziorany) to $-87.2 \%$ in 2016 (Pomp. Rzepichy) - in May, from $-37.7 \%$ in 2013 (Senatorska) to $-87.8 \%$ in 2016 (Pomp. Rzepichy) - in June, from $-4.9 \%$ in 2014 (Pomp. Jeziorany) to $-92.3 \%$ in 2015 (Pomp. Rzepichy) - in July, from $-20.2 \%$ in 2015 (Senatorska) up to $-91.9 \%$ in 2013 (Witkowice and Pomp. Rzepichy) - in August and from $-71.5 \%$ in 2015 (Witkowice) up to $-97.6 \%$ in 2014 (Senatorska) - in September (see: Fig. 5).

Maximum values of annual daily totals at 13 stations in Cracow, calculated during 2013-2016 from the summer months, occurred in July 2014, however they were lower than the maximum daily rainfall totals from the multi-annual period: from $-5.5 \%$ (Pomp. Kujawy) up to $-55.8 \%$ (OŚ Kostrze) (see: Fig. 6). 


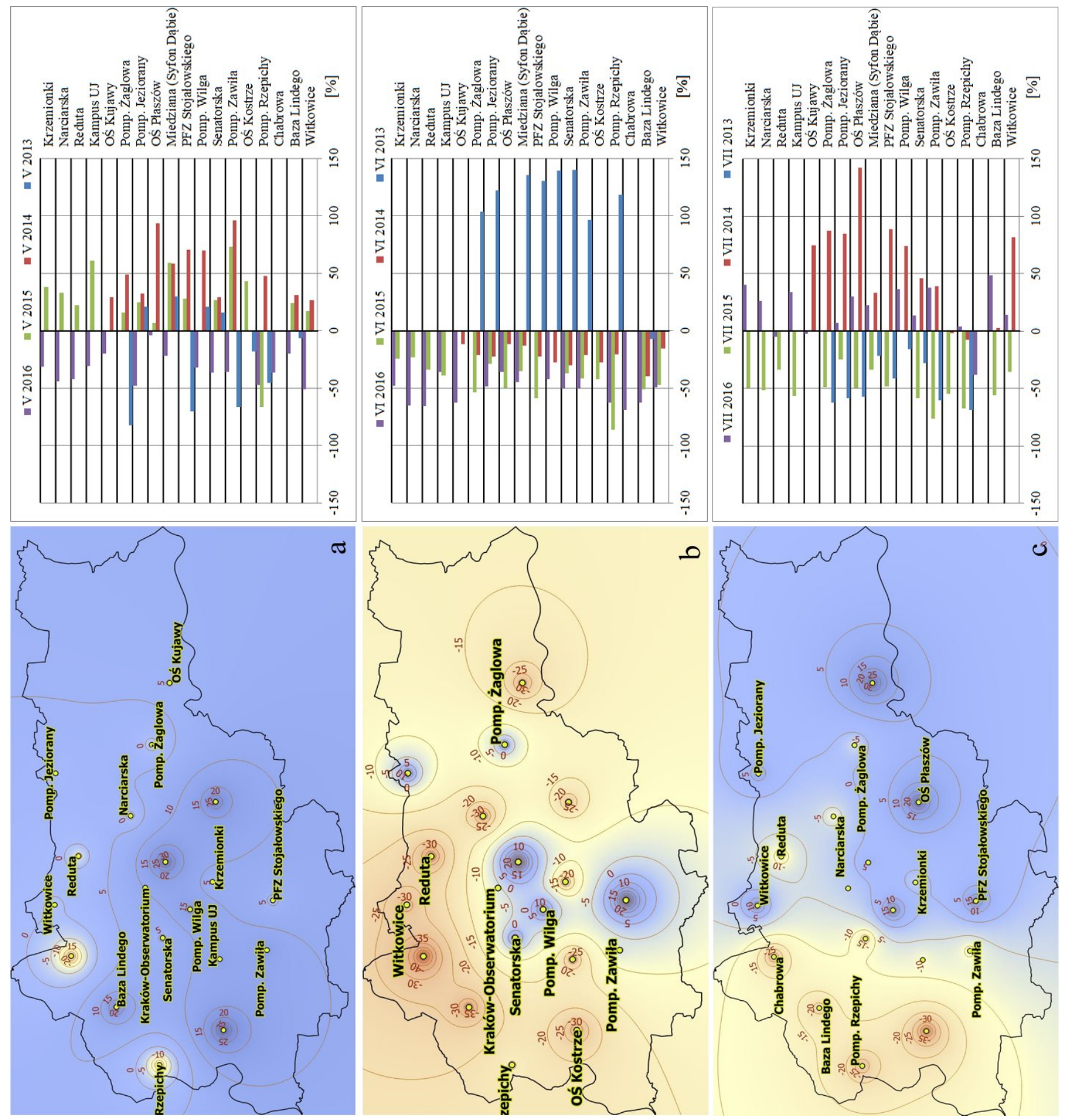




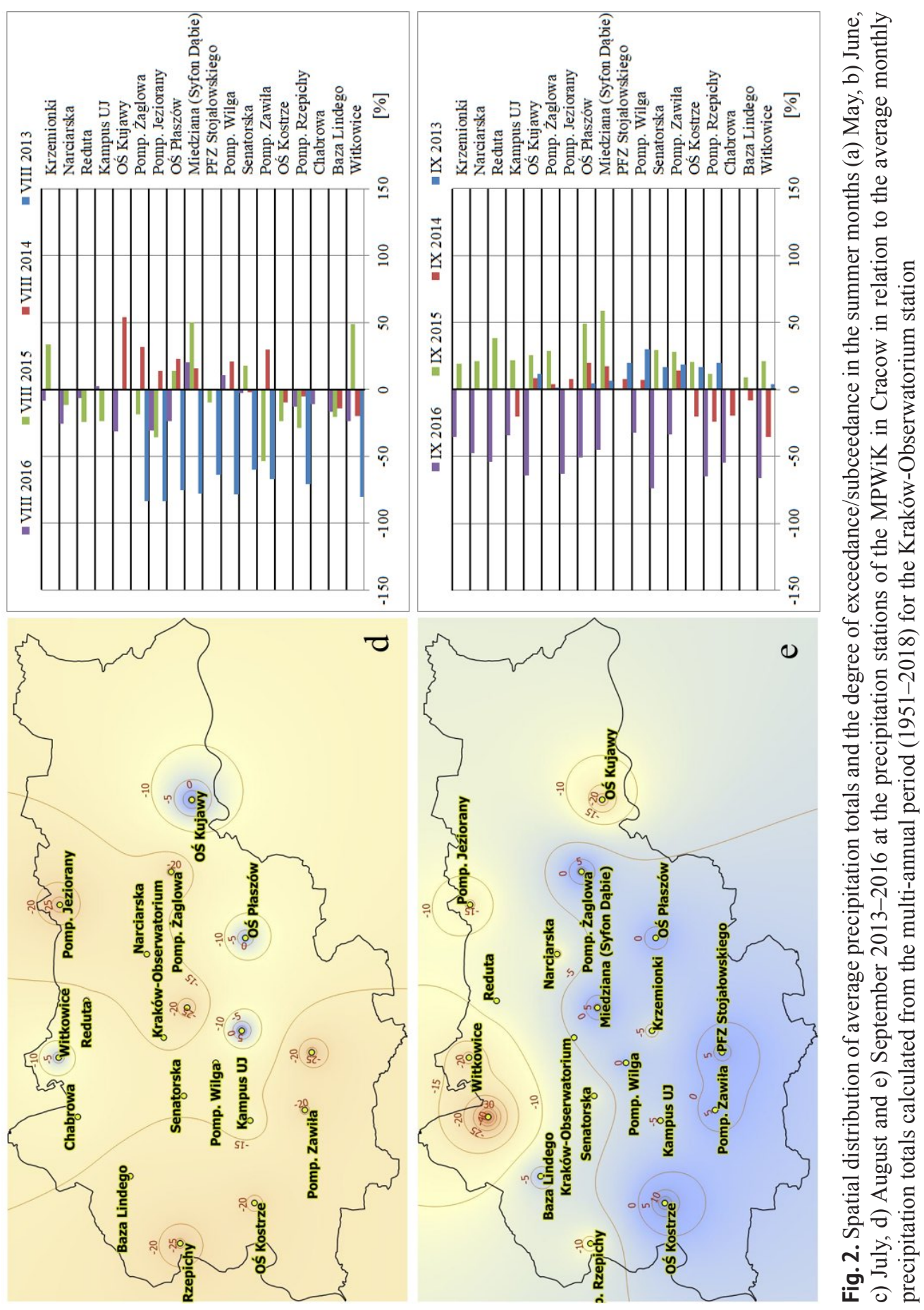




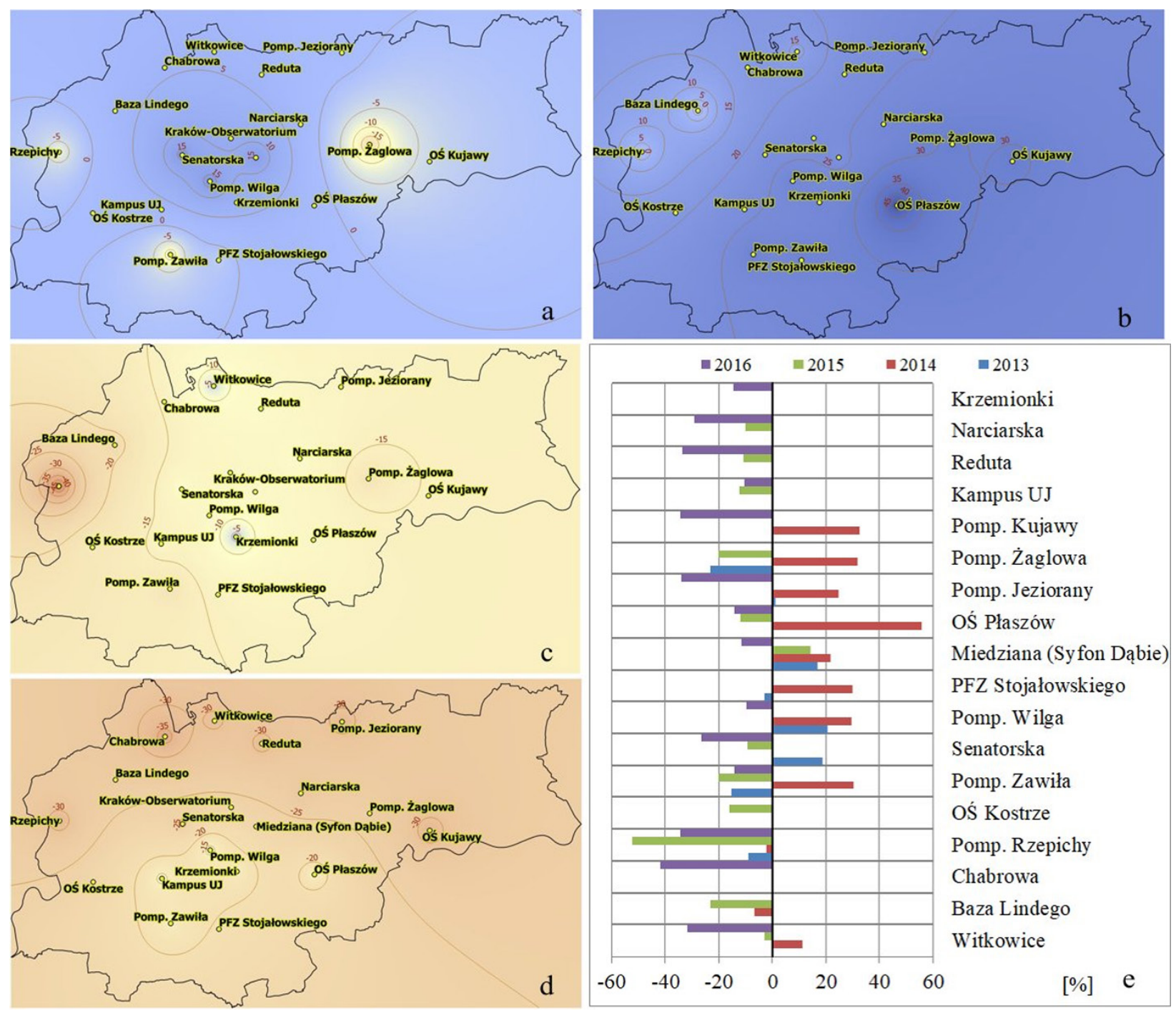

Fig. 3. Spatial distribution of the variability of the annual precipitation totals and the degree of exceedance/subceedance in the summer months in years: a) 2013, b) 2014, c) 2015, d) 2016 and e) 2013-2016 at the precipitation stations of the MPWiK in Cracow in relation to the average annual precipitation total calculated from the multi-annual period 1951-2018 for the Kraków-Obserwatorium station 


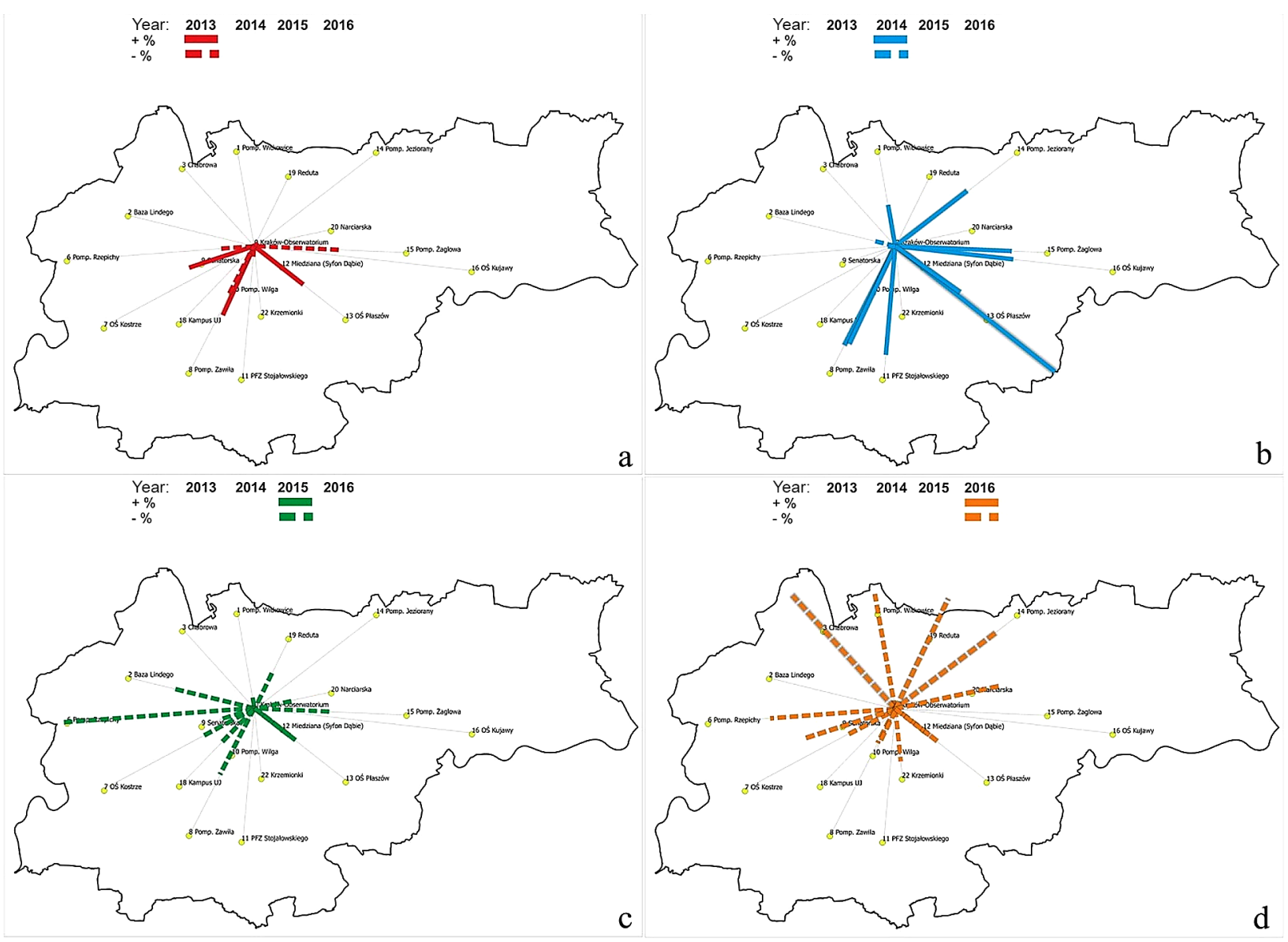

Fig. 4. Spatial distribution of average annual precipitation total in the Cracow area, represented by 18 precipitation stations in the summer months in years a) 2013, b) 2014, c) 2015 and d) 2016 in relation to the average annual precipitation total calculated from the multi-annual period 1951-2018 for the Kraków-Obserwatorium station

The trend analysis showed a decreasing value of the statistic S of the Mann-Kendall test (Table 3) which proves a decreasing trend in relation to the annual rainfall totals (V-IX) from the multi-annual period 1951-2018. Despite the existing trend of decreasing annual rainfall totals, no significant decreasing trend at $5 \%$ was found.
Table 3. Trend analysis for annual precipitation totals [in $\mathrm{mm}$ ] between May-September 1951-2018 (source: author's own calculations based on data from the Kraków-Obserwatorium station).

\begin{tabular}{|c|c|c|c|c|c|}
\hline & Range & $\begin{array}{c}\text { Mann- } \\
\text { Kendall } \\
\text { test } \\
\text { statistic S }\end{array}$ & $\begin{array}{l}\text { Kendall } \\
\text { statistic t }\end{array}$ & p-value & $\begin{array}{c}\text { Trend } \\
\text { at } 5 \% \\
\text { significance } \\
\text { level }\end{array}$ \\
\hline $219.8-1126.3$ & & -18.0 & -0.008 & 0.462 & lack \\
\hline
\end{tabular}


Jarosińska, E., Bodziony, M. (2019). Temporal and spatial rainfall variability in the urbanized area of Cracow. Acta Sci. Pol., Formatio Circumiectus, 18 (3), 43-55. DOI: http://dx.doi.org/10.15576/ASP.FC/2019.18.3.43

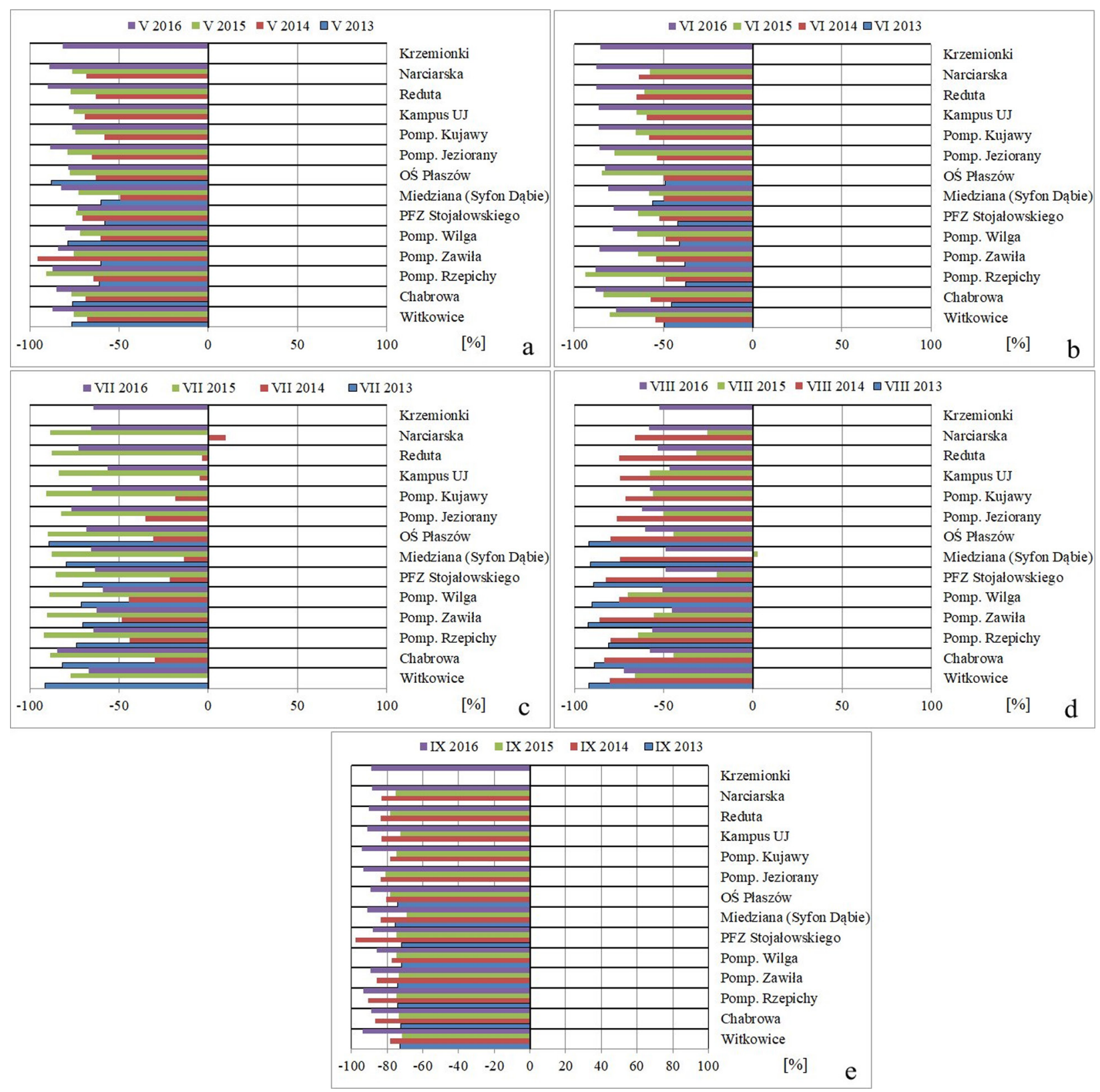

Fig. 5. The degree of exceedance/subceedance of the maximum daily precipitation totals calculated in the following months: a) May, b) June, c) July, d) August and e) September 2013-2016 in relation to the maximum annual precipitation totals calculated from the multi-annual period 1951-2018 for the Kraków-Obserwatorium station 

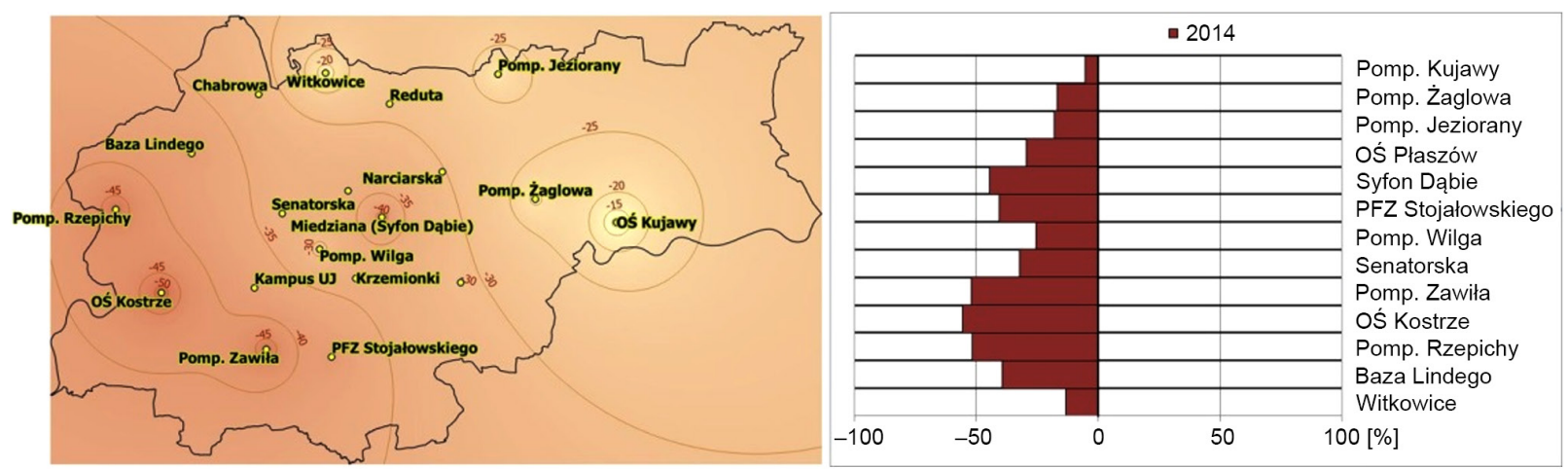

Fig. 6. Spatial distribution of precipitation in the Cracow area in Jul 2014 and the degree of subceedance of the maximum daily precipitation totals calculated in the summers months of 2013-2016 at the precipitation stations of the MPWiK in Cracow in relation to the maximum annual precipitation total calculated from the multi-annual period 1951-2018 for the Kraków-Obserwatorium station

\section{CONCLUSION}

The recent rainfall analysis in the Cracow area proves that:

1. despite the fact that the summer months of 2013 and 2014 were characterized by rainfalls exceeding the average values from the multi-annual period, the summer months in 2015 and 2016 showed a decreasing tendency in terms of rainfall quantity,

2. the shortage of rainfall in recent years calls for water retention in the periods of surplus (produced by intense rainfalls) and its release in periods of shortage in the city, as part of the efforts to sustainable precipitation water management. This is important due to: a) the decreasing temperature in the city (limiting urban heat islands), b) improving the city's microclimate, c) limiting local floods caused by intense rainfalls, which occur increasingly more often in the city as a result of convenient urban climate conditions,

3. the proposed methodology, as compared to the one currently in use in Poland: a) uses data from multiple precipitation stations in the researched area, b) allows for the comparison of precipitation quantities for a given period versus the data from the multi-annual period (utilizing a benchmark), c) makes it possible to continuously monitor precipitation variability occurring in the researched area, d) allows for quick creation of temporal-spatial precipitation distributions, enabling the identification of the areas of surplus or shortage of precipitation water,

4. obtaining detailed information regarding temporal -spatial precipitation variability, based on multiple precipitation stations, creates an opportunity for urban design to take into consideration the areas of the rainfall water surplus or shortage,

5. there is a need for continuous rainfall monitoring owing to the increasing urban sealing, as well as the possibility of utilizing data from multiple precipitation stations.

The analyses carried out using data from the short observation period as compared to the data from a multi-annual period require verification over a longer period of observation, which is taken into account in further research.

\section{ACKNOWLEDGMENTS}

This research was supported by the grant from Ministry of Science and Higher Education Ś1/391/2018/ DS. We would like to thank the MPWiK in Cracow for sharing the precipitation data. 


\section{REFERENCES}

Banasik, K., Hejduk, L., Hejduk, A., Kaznowska, E., Banasik, J., Byczkowski, A. (2013). Wieloletnia zmienność odpływu z małej zlewni rzecznej w regionie Puszczy Kozienickiej, Sylwan 157(8), 578-586.

Błażejczyk, K. (2013). Klimat i jego lokalne zróżnicowanie [in:] Degórska, B., Baścik, M., (Ed.). Środowisko przyrodnicze Krakowa Zasoby-Ochrona-Kształtowanie. Instytut Geografii i Gospodarki Przestrzennej Uniwersytetu Jagiellońskiego. Kraków. 61-68.

Bracken, L.J., Cox, N.J., Shannon J. (2008). The relationship between rainfall inputs and flood generation in south-east Spain. Hydrol. Process., 22, 683-696.

EEA Report No 16/2018. Trends and projections in Europe 2018. Tracking progress towards Europe's climate and energy targets. Luxembourg: Publications Office of the European Union. DOI:10.2800/931891. European Environment Agency.

Fendeková, M., Pekárová, P., Fendek, M., Pekár, J., \& Škoda, P. (2014). Global drivers effect in multi-annual variability of runoff, Journal of Hydrology and Hydromechanics, 62(3), 169-176. DOI: https://doi.org/ 10.2478/johh-2014-0027.

GUS 2019. Biuletyn Statystyczny Miasta Krakowa. I kwartał 2019 r. Urząd Statystyczny w Krakowie.

Ilnicki, P., Farat, R., Górecki, K., Lewandowski, P. (2015). Long-term air temperature and precipitation variability in the Warta River catchment area. Journal of Water and Land Development. No. 27 p. 3-13. DOI: 10.1515/jwld2015-0019.

Jarosińska, E. (2018). An analysis of short duration high-intensity rainfall events in Cracow area. Infrastructure and Ecology of Rural Areas, III(1). DOI: 10.14597/INFRAECO. 2018.3.1.038.

Jarosińska, E. (2019). An analysis of intense rainfalls in Cracow area [in:] Infrastructure and environment [online]/eds. Anna Krakowiak-Bal, Magdalena Vaverkova. Cham: Springer, 193-202. DOI: 10.1007/978-3-03016542-0_26. ISBN 978-3-030-16541-3.

Kędziora, A. (1995). Prognoza zmian klimatycznych. Prognoza ostrzegawcza zmian środowiskowych warunków życia człowieka w Polsce na początku XXI wieku. Zeszyty Naukowe Komitetu „Człowiek i Środowisko”, 10, Instytut Ekologii PAN, Oficyna wydawnicza, 97-132.

Kotowski, A., Dancewicz, A., Kaźmierczak, B. (2010). Czasowo-przestrzenne zróżnicowanie opadów atmosferycznych we Wroclawiu Ochrona Środowiska, 32, 4, 37-46.

Kaźmierczak, B., Kotowski, A., Wdowikowski, M. (2014). Analiza tendencji rocznych i sezonowych zmian wy- sokości opadów atmosferycznych w dorzeczu Górnej Odry. Ochrona Środowiska, 36, 3, 49-54.

Kożuchowski, K. (2016). Zawartość wody opadowej w atmosferze i opady w Polsce. Prz. Geof., 61, 3-4, 151-169 .

Lewińska, J. (2000). Klimat miasta: zasoby, zagrożenia, kształtowanie. Kraków: Instytut Gospodarki Przestrzennej i Komunalnej, Oddział w Krakowie.

Maksymiuk, A., Furmańczyk, K., Ignar, S., Krupa, J., Okruszko, T. (2008). Analiza zmienności parametrów klimatycznych i hydrologicznych w dolinie rzeki Biebrzy. Przegląd Naukowy Inżynieria I Kształtowanie Środowiska 3 (41), 59-68.

Matuszko, D. (2003). Cloudiness changes in Cracow in the 20th century, International Journal of Climatology, 23(8), 975-984, DOI: 10.1002/joc.887.

Matuszko, D. (Ed.) (2007). Klimat Krakowa w XX wieku. Instytut Geografii i Gospodarki Przestrzennej Uniwersytetu Jagiellońskiego, Kraków. 1-251.

Matuszko, D., Piotrowicz, K., Kowanetz, L. (2015). Klimat [in:] M. Baścik, B. Degórska (red.). Środowisko przyrodnicze Krakowa Zasoby-Ochrona-Kształtowanie. Instytut Geografii i Gospodarki Przestrzennej Uniwersytetu Jagiellońskiego, Kraków, 81-108.

Matuszko, D., Węglarczyk, S. (2014). Effect of cloudiness on long-term variability in air temperature in Krakow. International Journal of Climatology, 34(1), 145-154, DOI: $10.1002 /$ joc.3672.

Matuszko, D., Węglarczyk, S. (2018). Long-term variability of the cloud amount and cloud genera and their relationship with circulation (Kraków, Poland), International Journal of Climatology, DOI: 10.1002/joc.5445.

Molina-Sanchis, I., Lázaro, R., Arnau-Rosalén, E. \& Calvo-Cases, A. (2016). Rainfall timing and runoff: The influence of the criterion for rain event separation, Journal of Hydrology and Hydromechanics, 64(3), 226-236. DOI: https://doi.org/10.1515/johh-2016-0024.

MPA (2010, 2018). Plan Adaptacji Miasta Krakowa do zmian klimatu do roku 2030. Warszawa.

Nidzgorska-Lencewicz, J., Czarnecka, M. (2012). Wieloletnia zmienność sezonowych opadów w Polsce. Woda - Środowisko - Obszary Wiejskie (IV-VI) 12, 2(38), 45-60.

Nidzgorska-Lencewicz, J., Mąkosza, A. (2016). Specyficzne cechy klimatu miasta $\mathrm{w}$ aspekcie zdrowia człowieka. KOSMOS, 65, 4(313), 637-645.

Olechnowicz-Bobrowska, B., Skowera, B., Wojkowski, J., Ziernicka-Wojtaszek, A. (2005). Warunki opadowe na stacji agrometeorologicznej w Garlicy Murowanej. Acta Agrophysica, 6(2), 455-463. 
Radzka, E. (2014). Classification of precipitation intensity during vegetation season in central-eastern Poland (1971-2005). Journal of Ecological Engineering, 15, 3, 51-55. DOI: 10.12911/22998993.1109123.

Rutkowska, A., Ptak, M. (2012). On certain stationary tests for hydrological series. Studia Geotechnica et Mechanica, 34(1), 51-63.

Sun, B., Groisman, P.Y. (2000). Cloudiness variations over the former Soviet Union, International Journal of Climatology, 20 (10), 1097-1111, DOI: 10.1002/1097-0088 (200008)20:10<1097:AID-JOC541>3.0.CO; 2-5.

Szwed, M. (2019). Variability of precipitation in Poland under climate change, Theor Appl Climatol, 135, 1003. https://doi.org/10.1007/s00704-018-2408-6.

Twardosz, R., Cebulska, M., Walanus, A. (2016). Anomalously heavy monthly and seasonal precipitation in the Po- lish Carpathian Mountains and their foreland during the years 1881-2010. Theor Appl Climatol, 126, 323-337. https://doi.org/10.1007/s00704-015-1570-3.

Węglarczyk, S. (2010). Statystyka w inżynierii środowiska. Kraków: Wydawnictwo PK.

Wibig, J. (2008). Cloudiness variations in Łódź in the second half of the 20th century, International Journal of Climatology, 28(4), 479-491, DOI: 10.1002/joc.1544.

Wibig, J. (2009). The variability of daily precipitation totals in Poland (1951-2000). Geogr. Pol 82(1), 21-32.

Vitola, I., Vircavs, V., Abramenko, K., Lauva, D. \& Veinbergs, A. (n.d.). (2012). Precipitation and Air Temperature Impact on Seasonal Variations of Groundwater Levels, Environmental and Climate Technologies, 10(1), 25-33. DOI: https://doi.org/10.2478/v10145-012-0022-x.

\section{CZASOWO-PRZESTRZENNA ZMIENNOŚĆ DESZCZU NA ZURBANIZOWANYM OBSZARZE KRAKOWA}

\section{ABSTRAKT}

\section{Cel pracy}

Celem pracy jest charakterystyka czasowo-przestrzennego zróżnicowania rozkładu deszczu na obszarze miasta Krakowa, oparta na nowym sposobie określania przestrzennego rozkładu, a także wyznaczenie obszarów o najmniejszych i największych zmiennościach opadu w stosunku do wielolecia.

\section{Materiały i metody \\ Materiał:}

Do obliczeń zostały przyjęte 10-minutowe ciągi danych opadowych opadu z lat 2013-2016 oraz dobowe i miesięczne ciągi danych z wielolecia 1951-2018 (zarejestrowane przez system monitoringu deszczowego MPWiK w Krakowie, 18 stacji opadowych) a dane z wielolecia (z bazy danych IMGW dla posterunku Kraków-Obserwatorium).

\section{Metoda:}

Dokonano porównania deszczy zaobserwowanych w latach 2013-2016 z deszczami z wielolecia 1951-2018 w zakresie średniej miesięcznej i rocznej sumy deszczu oraz maksymalnych sum dobowych deszczy w miesiącach letnich. Porównania dokonano określając stopień zaniżenia lub przewyższenia wartości średnich w [\%] względem posterunku Kraków-Obserwatorium, który uznany został za reper porównawczy.

Ostatnim etapem badań było opracowanie, w środowisku geoinformacyjnym, rastrowych map przestrzennego rozkładu deszczu na obszarze Krakowa. Do utworzenia izolinii wykorzystana została metoda interpolacji.

\section{Wyniki i wnioski}

Proponowana metoda, w odróżnieniu od dotychczas stosowanych w Polsce: a) wykorzystuje dane z wielu posterunków opadowych na badanym obszarze, b) pozwala na porównanie wielkości opadów dla danego okresu z danymi z wielolecia (z wykorzystaniem repera porównawczego), c) umożliwia ciągły monitoring zmian opadów zachodzących na badanym obszarze, d) pozwala na tworzenie w szybki sposób przestrzenno-czasowych rozkładów opadu, umożliwiających identyfikację obszarów z nadmiarem lub niedoborem wody opadowej.

Słowa kluczowe: deszcz, monitoring opadowy, obszar zurbanizowany, klimat miejski 